\title{
Milling, Nutritional, Physical and Cooking Properties of Four Basmati Rice Varieties
}

\author{
Pravin Ojha ${ }^{1 @}$, Omkar Chaudhary $^{2}$, Ujjwol Subedi $^{1}$, Roman Karki $^{1}$ and Durga Man Singh Dongol ${ }^{1}$ \\ ${ }^{1}$ Food Research Division, Nepal Agricultural Research Council, Lalitpur, Nepal; @: projha84@ gmail.com; \\ (iD https://orcid.org/0000-0002-1103-5984; US <uj.subedi@gmail.com>; RK <karki.roman@ gmail.com>; DMSD \\ <durgadangol@yahoo.com> \\ ${ }^{2}$ National College of Food Science and Technology, Kathmandu, Nepal; <omee_forall@yahoo.com>
}

Received 12 Nov 2016, Resubmitted 24 October 2017, Accepted 5 Jan 2018,

Published 28 April 2018

Scientific Editors: Jiban Shrestha, Hari Krishna Upreti

Copyright $@ 2018$ NARC. Permits unrestricted use, distribution and reproduction in

any medium provided the original work is properly cited

\begin{abstract}
Rice is one of the most popular staple foods produced contributing higher most in agriculture gross domestic production in Nepal. Thus, nutritional, physicochemical, and cooking properties of rice might interplay important roles in their production and farming practice, therefore, it is inevitable to understand these characteristic features. However, there has been only limited information available on such properties, therefore we aimed to examine nutritional, physicochemical and cooking properties of four Basmati varieties of rice namely Red Basmati, White Basmati, Black Basmati and Pokhareli Basmati. These rice varieties were purchased from different places in Nepal in paddy form. In this study various parameters associated with milling, nutritional, physical and cooking properties were evaluated. To measure protein contents in rice, Kjeldal method was implied. Among the varieties, the protein content was maximum in Red Basmati (7.74\%) and minimum in Black Basmati $(6.51 \%)$. The milled rice percentage and head rice recovery were maximum in Pokhareli Basmati represented by $72.02 \pm 0.10$ and $67.46 \pm 0.42$, respectively, while and minimum in White Basmati represented by $68.17 \pm 0.50$ and $65.11 \pm 0.28$, respectively. The kernel elongation ratio and volume expansion ratio was maximum in Red Basmati represented by 1.62 and 2.85 respectively. Water uptake ratio was maximum 3.11 in Black Basmati and minimum of 2.18 in Red Basmati. Gruel loss was found lowest $1.05 \%$ in Red Basmati and highest represented by $2.40 \%$ in Black Basmati. The highest starch iodine blue value of 0.21 was observed in Red Basmati and lowest of 0.12 in Black Basmati. The Red Basmati was found to have the better cooking quality among all varieties.
\end{abstract}

Keywords: Alkali spreading, Degree of milling, Gruel loss, Water uptake ratio

\section{सारांश}

चार वटा बासमती जातको (सेतो, रातो, कालो र पोखरेली) चामलको पौष्टिक, भौतिक-रासायनिक र पकाए पछिको गुणस्तर अध्ययन गरियो, सो मध्ये रातो बासमतीमा प्रोटिनको मात्रा ७.७४\% कालो बासमतीमा ६. ४१\% भेटियो। पोखरेली चामलमा चामल पर्ने र सग्लो चामल प्रतिशत सबभन्दा बेसी ७२.०२\%, रहेको पाइयो भने, सबभन्दा कम ६६.१७\% सेतो बासमतीमा पाइयो। पकाउंदा रातो बासमतीको सिताको लम्बाई र फैलावटको अनुपात र आयतन फैलावट अनुपात क्रश १.६२ र २.६५ र पाइयो। कालो बासमतीमा पानी सोस्ने क्षमता सबभन्दा बेसी (३.११ गुना) पाइयो भने सबभन्दा कम (२.१६ गुना) रातो बासमतीमा भेटियो। माँडमा सबभन्दा कम ठोस पदार्थ रातो बासमतीमा (१.०५\%) भेटियो भने सबभन्दा बेसी कालो बासमतीमा (२.४\%\%) भेटियो। सबभन्दा बेसी स्टार्च-आयोडिन निलो अंक रातो बासमतीमा (O.२१) भेटियो भने सबभन्दा कम कालो बासमतीमा (०.१२) भेटियो । अन्तत, पकाए पछिको गुणस्तर रातो बासमतीमा सबभन्दा राम्रो पाइयो ।

\section{INTRODUCTION}

Rice (Oryza sativa L.) farming in the national economy contributes highest from agriculture sector. Rice is cultivated in a wide range of agro-climate regions under varying topography climates and altitudes in Nepal. Nepalese farmer prefers to grow rice varying from 60 meters in Tarai to 3050 meters above sea level in hills. Rice is not only the staple food, but straw provides dependable source of cattle feed all the year around (MoAD 2015). A total of 57 inbred rice genotypes have been released and 17 hybrid rice varieties have been registered (sqcc.gov.np/NARC 2014, MoAD 2015) and the rice provides about $40 \%$ of the total calorie requirement of Nepalese people (MoAD 2015).

The importance of rice as the main source of food particularly in developing countries is ever increasing since last 30 years (Gao et al 2002, Bouis et al 2003). Study on nutritional quality of rice has received more attention in the developing countries. 
Since rice is a major cereal grain, the highest priority is thus given to the physiochemical, nutritional and cooking qualities of rice (Tan et al 1999). Such preference of consumer based on the taste and type of their origin (Azabagaoglu and Gaytancioglu 2009) might cause promotion or demotion of the cultivation of specific variety. The genetics and the environmental factors in which rice are grown causes the variations in composition and cooking quality of rice (Singh et al 2005). The physiochemical characteristics affect the cooking behavior and texture of cooked rice defined as the rice grain quality (Bocevska et al 2009). Although many works on nutritional characteristics of Basmati rice are known to be studied, however, characteristic features of Basmati rice in Nepal were seldom carried out, therefore, our major objective was to evaluate four varieties of Basmati rice of Nepal.

\section{MATERIALS AND METHODS}

The laboratory experiment was conducted in Food Research Division, Nepal Agricultural Research Council (NARC) Nepal. For the purpose, five kilograms of paddy samples of four Basmati rice varieties namely Red Basmati, White Basmati, Black Basmati and Pokhareli Basmati were purchased on January first week, 2014from, Jhapa (Itabhatta chowk, Sanischare), Sunsari (Duhabi, Nimuwa), Morang (Rangeli, Bhaluwa), Siraha, Dhanusha, Parsa, Bara and Kathmandu (Dakshinkali, Chaimale). The completely randomized design with five replicates of each sample was applied for the determination parameter such as milling quality, milling recovery, head rice yield, carbohydrate, crude protein, cooking quality etc. All the samples were brought to the laboratory, transferred into cotton bags and stored at room temperature for analysis.

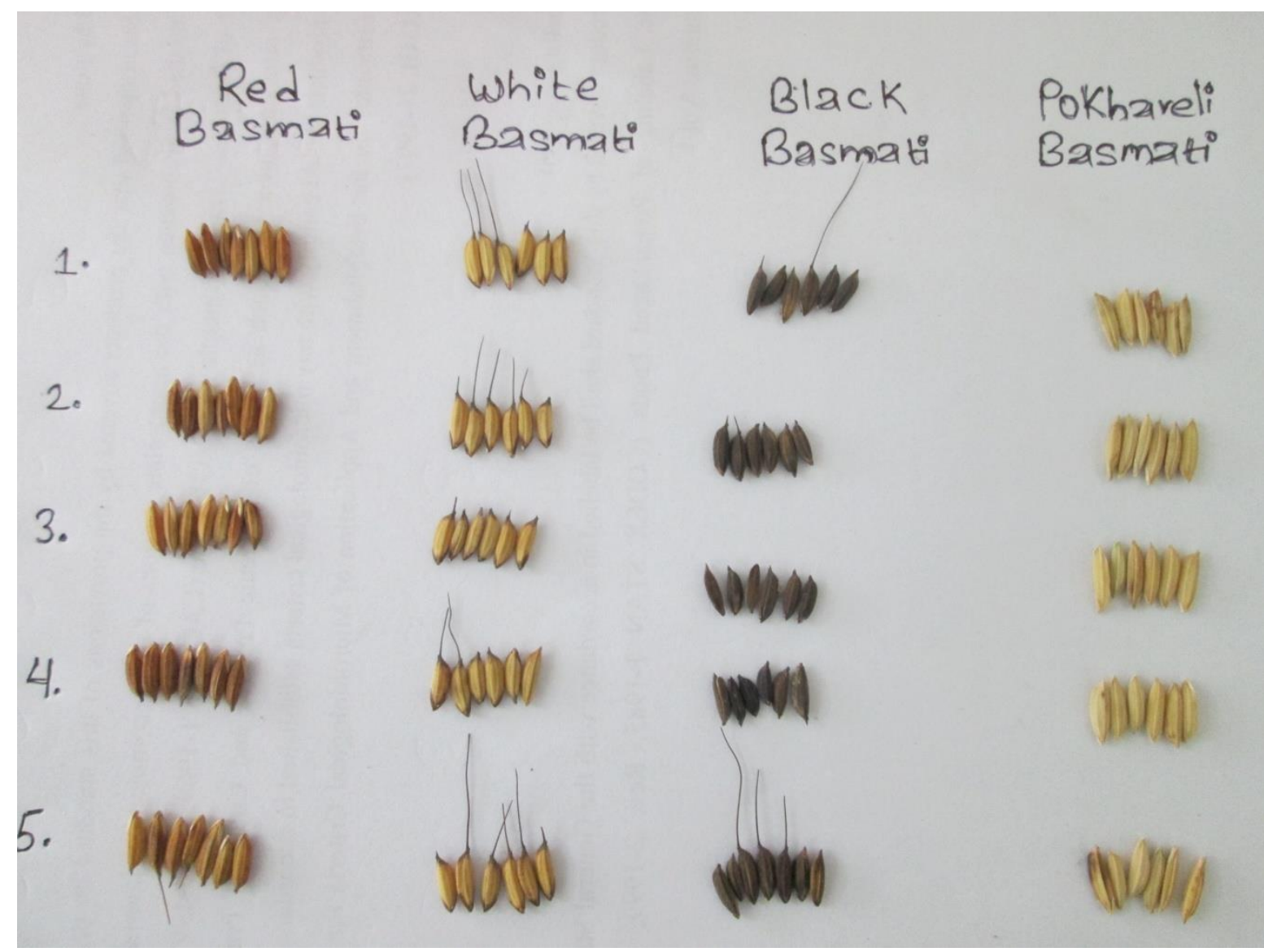

Figure 1. Four Varieties of Basmati paddy.

Milling Quality of Rice

Milling yield of paddy is the estimate of the quantity of the head rice and of the total yield of milled rice that can be produced from a unit of paddy (Bhattacharya 2011).

Milling recovery and head rice yield was calculated as follows:

Milling recovery $\%=($ Weight of milled rice/Weight of paddy $) \times 100 \%$

Head rice yield $\%=($ Weight of head rice/Weight of milled rice $) \times 100 \%$ 
The degree of milling (DM) is defined as the percentage of bran removed from the brown rice during milling. The mean grain weight of the brown rice $(\mathrm{mBR})$ and of the milled rice $(\mathrm{mMr})$ and calculation was carried by the equation given by Bhattacharya (2011):

$$
D M=\frac{m B R-m M R}{m B R} \times 100 \%
$$

\section{Nutritional Quality of Rice}

Carbohydrate was calculated by weight difference method and moisture, crude protein, crude fat, crude fiber, ash content was determined as given by Rangana (2002). Moisture content was determined by drying the sample in a hot air oven at $105 \pm 1^{\circ} \mathrm{C}$ to a constant weight. Crude protein was calculated from the nitrogen content measured by Kjeldahl method, multiplying total nitrogen by factor 6.25 . Crude fat was determined by continuous extraction in a soxhlet apparatus for 3 hours using petroleum ether as solvent. The fat was recovered by evaporating away the solvent. Ash content was determined by incinerating the sample at $550^{\circ} \mathrm{C}$ in a muffle furnace.

Physical Measurement of Paddy and Rice

A thousand kernels were counted from the sample for determining the weight using the electronic balance and expressed in grams and bulk density was expressed in $\mathrm{kg} / \mathrm{hL}$ as described in Bhattacharya (2011). Rice caliper was used to measure length (L) and breadth (B) of the rice. L/B ratio was then calculated by using data obtained as per described by Bhattacharya (2011).

\section{Cooking Quality of Rice}

Six whole milled kernels from each sample were evenly placed in a small petri dish containing $25 \mathrm{ml}$ of $1.5 \%$ $\mathrm{KOH}$ solution and left undisturbed for 24 hours at room temperature. Then the sample was scored for spreading and clearing according to seven point scales as Bhattacharya (1971) has mentioned. Then, about $5 \mathrm{~g}$ milled rice was poured into a test tube containing $25 \mathrm{ml}$ water which was arranged in $\left(80^{\circ} \mathrm{C}\right)$ water bath for 15 minutes. Then the cooked rice was immediately washed once with about $25 \mathrm{ml}$ cooled distilled water stirring with bent wire to minimize over-cooking. Then the fluid portion was drained into the tarred crucible for the determination of gruel loss. The excess moisture remained in the cooked rice sample was soaked by gentle pressing with a hand in between the filter paper. It was immediately weighted in electric balance and water uptake ratio was determined as given by Oko et al (2012):

$$
\text { Water uptake ratio }=\frac{\text { weight of cooked rice }}{\text { weight of uncooked rice }} \times 100 \%
$$

Volume expansion ratio was determined by the method given by Rout (2006) using the formula given below:

$$
\text { Volume expansion ratio }=\frac{\text { Vol. of cooked sample of rice }(\mathrm{Y})}{\text { Vol. of raw sample of rice }(\mathrm{X})} \times 100 \%
$$

Elongation ratio was also calculated following the method mentioned by Rout (2006)

$$
\text { Elongation ratio }=\frac{\text { Average length of cooked kernel }(\mathrm{mm})}{\text { Average length of uncooked kernel }(\mathrm{mm})} \times 100 \%
$$

The amount of total solid occurred in cooking water is called gruel and the gruel fluid obtained during the experiment by water uptake was drained in tarred crucible and was placed into the hot air oven at $100^{\circ} \mathrm{C}$ for 24 hours. The weight of the residue was measured with the help of electronic balance.

$$
\text { Gruel loss } \%=\frac{\text { weight of residue }}{\text { weight ofsample (rice) }} \times 100
$$

Then the gruel loss (dry wt. basis) was determined and expressed the value after correction in $\%$. The data correction was done as:

Dry weight of samples= weight of sample taken- weight of moisture in the sample.

For starch iodine value, ground rice sample was passed through a simple sieve and $1 \mathrm{~g}$ powder was transferred to a $250 \mathrm{ml}$ Erlenmeyer flask. On which, $100 \mathrm{ml}$ distilled water (D/W) was added and the flask was immersed into the serological water bath at $77^{\circ} \mathrm{C}$ for 15 minutes. The flask was removed from the water bath and allowed 
to stand for 15 minutes at room temperature and filtered through Whattman No. 42 filter paper. First 30-40 ml of filtrate was discarded. Then, $10 \mathrm{ml}$ aliquot of the filtrate was pipetted into $100 \mathrm{ml}$ volumetric flask containing 1 $\mathrm{ml} \mathrm{30 \%} \mathrm{HCL} \mathrm{and} 1 \mathrm{ml}$ of iodine solution (prepared by dissolving $2 \mathrm{~g}$ iodine in 1 litre solution of KI). After that 60 to $70 \mathrm{ml}$ distilled water was added, shaken well and final volume was made up to the mark with distilled water. It was allowed to stand for 30 minutes at room temperature. The intensity of the blue color was determined in the spectrophotometer (Systronics spectrophotometer 105, range: $340-960 \mathrm{~nm}$ ) at $620 \mathrm{~nm}$ and optical density was recorded. In the instrument, the percentage of transmittance was set at 100 with blank (100 $\mathrm{ml}$ together with $1 \mathrm{ml} \mathrm{HCL}$ solution, $1 \mathrm{ml}$ iodine solution and distilled water).

Minimum cooking time was determined by the method of Ranghino (1966). Starting after 10 min of cooking in boiling water at least 10 grains was pressed between two glass plates every minute. Cooking time was evaluated when $90 \%$ of the grains no longer showed an opaque center. Then optimum cooking time was calculated as minimum cooking time plus 2 minutes.

Statistical Analysis

The data were analyzed statistically by using one factor analysis of variance (ANOVA) in a completely randomized design by using Genstat discovery (Win 32) edition 4. The significant differences between treatments were tested at $5 \%$ level of significance by using LSD.

\section{RESULTS}

Milling Quality Characters

The milling quality parameters of different paddy are shown in Table 1. The milling yield in White Basmati,

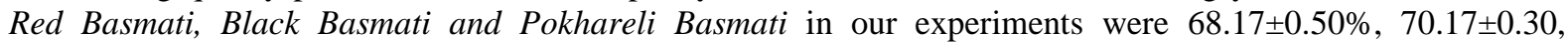
$71.66 \pm 0.38 \%$ and $72.02 \pm 0.10 \%$, respectively. The head rice recovery was found to be maximum in Pokhareli Basmati $(67.46 \%)$ and minimum in White Basmati $(65.10 \%)$. Statistical analysis showed that there was a significant $(\mathrm{p}<0.05)$ difference in milling yield among the tested varieties. The mean length and breadth of White, Red, Black and Pokhareli Basmati paddy was $8.04 \mathrm{~mm} \pm 2.24 \mathrm{~mm}, 8.16 \mathrm{~mm} \pm 2.56 \mathrm{~mm}, 7.53 \mathrm{~mm} \pm 2.17$ $\mathrm{mm}$ and $9.53 \mathrm{~mm} \pm 2.33 \mathrm{~mm}$, respectively.

The statistical data showed that there is significant difference $(\mathrm{p}<0.05)$ at $5 \%$ level of significant in terms of length and breadth in between all four varieties.

Table 1. Milling quality parameters of different Paddy varieties.

\begin{tabular}{|c|c|c|c|c|c|c|c|c|c|c|}
\hline Variety & $\begin{array}{l}\text { Length of } \\
P(\mathrm{~mm})\end{array}$ & $\begin{array}{l}\text { Breadth of } \\
P(\mathrm{~mm})\end{array}$ & $\begin{array}{l}\text { L/B Ratio } \\
\text { of P }\end{array}$ & $\begin{array}{l}\text { Brown Rice } \\
\%\end{array}$ & Husk \% & $\begin{array}{l}\text { Milled Rice } \\
\%\end{array}$ & $\begin{array}{l}\text { Degree of } \\
\text { Milling }\end{array}$ & $\begin{array}{l}\text { Head Rice } \\
\%\end{array}$ & $\begin{array}{l}\text { Broken } \\
\%\end{array}$ & $\begin{array}{r}\% \text { of } \\
\text { Chalky }\end{array}$ \\
\hline $\begin{array}{l}\text { White } \\
\text { Basmati }\end{array}$ & $8.04 \pm 0.03^{\mathrm{a}}$ & $2.24 \pm 0.04^{\mathrm{a}}$ & $3.59 \pm 0.06^{\mathrm{a}}$ & $77.62 \pm 0.16^{\mathrm{a}}$ & $22.38 \pm 0.18^{\mathrm{a}}$ & $68.17 \pm 0.50^{\mathrm{a}}$ & $9.45 \pm 0.37^{\mathrm{a}}$ & $65.10 \pm 0.21^{\mathrm{a}}$ & $\begin{array}{l}3.06 \\
\pm 0.62^{\mathrm{a}}\end{array}$ & $0.80 \pm 0.02^{\mathrm{a}}$ \\
\hline $\begin{array}{l}\text { Red } \\
\text { Basmati }\end{array}$ & $8.16 \pm 0.01^{b}$ & $2.56 \pm 0.02^{b}$ & $3.62 \pm 0.03^{\mathrm{a}}$ & $78.92 \pm 0.26^{\mathrm{b}}$ & $21.08 \pm 0.26^{\mathrm{b}}$ & 70.17 & $\begin{array}{l}8.75 \pm \\
0.23^{b}\end{array}$ & $65.15 \pm 0.16^{\mathrm{a}}$ & $\begin{array}{l}5.01 \\
\pm 0.36^{\mathrm{b}}\end{array}$ & $0.27 \pm 0.01^{b}$ \\
\hline $\begin{array}{l}\text { Black } \\
\text { Basmati }\end{array}$ & $7.53 \pm 0.36^{\mathrm{c}}$ & $2.17 \pm 0.01^{c}$ & $3.48 \pm 0.03^{b}$ & $79.34=$ & $20.65 \pm 0.25^{\mathrm{c}}$ & $71.66 \pm 0.38^{\mathrm{c}}$ & $\begin{array}{l}8.28 \pm \\
0.55^{\mathrm{c}}\end{array}$ & $67.19 \pm 0.33^{b}$ & $\begin{array}{l}3.87 \\
\pm 0.54^{\mathrm{c}} \\
\end{array}$ & $0.25 \pm 0.02^{\mathrm{c}}$ \\
\hline $\begin{array}{l}\text { Pokhareli } \\
\text { Basmati }\end{array}$ & $9.53 \pm 0.01^{\mathrm{d}}$ & $2.33 \pm 0.02^{\mathrm{d}}$ & $4.10 \pm 0.03^{\mathrm{c}}$ & $80.57 \pm 0.41^{\mathrm{d}}$ & $19.43 \pm 0.41^{\mathrm{d}}$ & $72.02 \pm 0.10^{\mathrm{d}}$ & $\begin{array}{l}8.55 \pm \\
0.35^{\mathrm{d}}\end{array}$ & $67.46 \pm 0.42^{\mathrm{c}}$ & $\begin{array}{l}4.56 \\
\pm 0.50^{\mathrm{d}}\end{array}$ & $0.11 \pm 0.01^{\mathrm{d}}$ \\
\hline LSD & 0.0335 & 0.0302 & 0.0539 & 0.3923 & 0.3923 & 0.4725 & 0.534 & 0.405 & 0.693 & 0.0173 \\
\hline
\end{tabular}

Values are mean of five replicate determination and values after sign plus/minus $( \pm)$ indicate standard deviation

Superscript letters $(a-d)$ indicate significant difference $(p<0.05)$ among different rice varieties. Means with same letter within column are not significantly different $(p<0.05)$.

\section{Nutritional Composition}

The nutritional composition of the tested varieties of rice examined were carbohydrates, protein, fat, fiber and ash. The results of the measured parameters and are shown in Table 2. The result shown that there was significant $(\mathrm{p}<0.05)$ difference in moisture, fat, fiber, ash and carbohydrate content among all varieties. The mean moisture content was $13.00 \%$ in White Basmati, $13.01 \%$ in Red Basmati, $12.84 \%$ in Black Basmati and $12.82 \%$ in Pokhareli Basmati. The statistical analysis in terms of moisture showed that there was no significant $(\mathrm{p}<0.05)$ difference in between all varieties, though there is slight difference between Black and Pokhareli basmati. The fat, fiber and ash content in Pokhareli Basmati were $0.74 \%, 0.71 \%$ and $0.71 \%$, respectively. These values were higher comparing to other varieties. The protein and ash content in black Basmati was $6.51 \pm 0.09 \%$ and $0.51 \pm 0.01 \%$, respectively, which were lower than other varieties (Table 2). The moisture content of all varieties of rice was not found significantly $(\mathrm{p}<0.05)$ different from each other. The proximate analysis of Pokhareli Basmati showed comparatively nutritionally rich in comparison to other varieties (Table 2). 
Table 2. Compositional comparison of different rice varieties measured on dry basis.

\begin{tabular}{llllllr}
\hline Variety & Moisture & Crude Protein & Crude Fiber & Crude Fat & Ash & Carbohydrate $^{\text {White Basmati }}$ \\
\hline Wh.00 \pm 0.009 & $6.92 \pm 0.123^{\mathrm{a}}$ & $0.25 \pm 0.005^{\mathrm{a}}$ & $0.36 \pm 0.011^{\mathrm{a}}$ & $0.57 \pm 0.015^{\mathrm{a}}$ & $91.89 \pm 0.121^{\mathrm{a}}$ \\
\hline Red Basmati & $13.01 \pm 0.013$ & $7.74 \pm 0.102^{\mathrm{b}}$ & $0.17 \pm 0.013^{\mathrm{b}}$ & $0.26 \pm 0.013^{\mathrm{b}}$ & $0.55 \pm 0.004^{\mathrm{b}}$ & $91.28 \pm 0.1019^{\mathrm{b}}$ \\
\hline Black Basmati & $12.84 \pm 0.054$ & $6.51 \pm 0.097^{\mathrm{c}}$ & $0.19 \pm 0.001^{\mathrm{c}}$ & $0.53 \pm 0.016^{\mathrm{c}}$ & $0.51 \pm 0.013^{\mathrm{c}}$ & $92.25 \pm 0.115^{\mathrm{c}}$ \\
\hline $\begin{array}{l}\text { Pokhareli } \\
\text { Basmati }\end{array}$ & $12.80 \pm 0.07$ & $7.31 \pm 0.172^{\mathrm{d}}$ & $0.71 \pm 0.007^{\mathrm{d}}$ & $0.74 \pm 0.008^{\mathrm{d}}$ & $0.71 \pm 0.018^{\mathrm{d}}$ & $90.53 \pm 0.16^{\mathrm{d}}$ \\
\hline LSD & & 0.1708 & 0.013 & 0.0168 & 0.0181 & 0.1692 \\
\hline Va
\end{tabular}

Values are mean of five replicate determination and values after sign plus/minus ( \pm ) indicate standard deviation. Superscript letters (a-d) indicate significant differences $(p<0.05)$ among different rice varieties. Means with same letter within column are not significantly different $(p<0.05)$

Physical Quality of Rice

The length and breadth of White Basmati, Red Basmati, Black Basmati and Pokhareli Basmati was respectively found as $5.14 \mathrm{~mm}: 2.08 \mathrm{~mm} ; 5.60 \mathrm{~mm}: 2.01 \mathrm{~mm} ; 5.10 \mathrm{~mm}: 1.97 \mathrm{~mm}$; and $6.15 \mathrm{~mm}: 2.00 \mathrm{~mm}$. The length and breadth rations were significantly $(\mathrm{p}<0.05)$ different among the tested varieties. The length-breadth ratio was

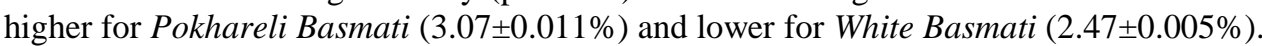

Table 3. Physical and cooking properties of different rice varieties

\begin{tabular}{|c|c|c|c|c|c|c|c|c|c|c|c|}
\hline ariety & $\begin{array}{l}\text { Length of } \\
\mathrm{R}(\mathrm{mm})\end{array}$ & $\begin{array}{l}\text { Breadt } \\
\text { h of R } \\
(\mathrm{mm})\end{array}$ & $\begin{array}{l}\text { L/B } \\
\text { Ratio of } \\
\text { Rice }\end{array}$ & $\begin{array}{l}1000 \\
\text { kernel } \\
\text { weight } \\
(\mathrm{g})\end{array}$ & $\begin{array}{l}\text { Bulk } \\
\text { Density } \\
\text { (Kg hL-1) }\end{array}$ & $\begin{array}{l}\text { Kernel } \\
\text { elong. } \\
\text { Ratio }\end{array}$ & $\begin{array}{l}\text { Water } \\
\text { uptake } \\
\text { ratio }\end{array}$ & $\begin{array}{l}\text { Gruel } \\
\text { Loss \% }\end{array}$ & $\begin{array}{l}\text { Volume } \\
\text { expan. Ratio }\end{array}$ & $\begin{array}{l}\text { Starch } \\
\text { iodine } \\
\text { value }\end{array}$ & $\begin{array}{r}\text { Alkali } \\
\text { spreading }\end{array}$ \\
\hline smati & $5.14 \pm$ & $\begin{array}{l}2.08 \pm 0 \\
.01^{\mathrm{b}}\end{array}$ & 2. & $\begin{array}{l}13.46 \pm 0.0 \\
4^{\mathrm{a}}\end{array}$ & & $\begin{array}{l}1.43 \\
7^{\mathrm{a}}\end{array}$ & $\begin{array}{l}2.31 \\
9^{\mathrm{a}}\end{array}$ & & & $007^{\mathrm{a}}$ & 2.40 \\
\hline ed $\mathrm{F}$ & $5.60=$ & $\begin{array}{l}2.01 \pm 0 \\
.01^{\mathrm{a}} \\
\end{array}$ & $2.79 \pm$ & $\begin{array}{l}14.25 \pm 0.0 \\
8^{\mathrm{b}}\end{array}$ & $\begin{array}{l}78.4 \\
b\end{array}$ & $\begin{array}{l}1.62 \pm 0.01 \\
1^{\mathrm{b}}\end{array}$ & $\begin{array}{l}2.18 \pm 0.01 \\
1^{b}\end{array}$ & $\begin{array}{l}1.05 \\
0^{\mathrm{b}}\end{array}$ & & $\begin{array}{l}0.21 \pm 0 . \\
007^{\mathrm{b}}\end{array}$ & $2.40 \pm 0.42^{\mathrm{a}}$ \\
\hline lack & $5.10=$ & $\begin{array}{l}1.97 \pm 0 \\
.01^{\mathrm{c}}\end{array}$ & $\begin{array}{l}2.59 \pm 0.02 \\
c\end{array}$ & $\begin{array}{l}11.37 \pm 0.2 \\
1^{c}\end{array}$ & $\begin{array}{l}86.26 \pm 0.33 \\
\mathrm{c}\end{array}$ & $\begin{array}{l}1.47 \pm 0.01 \\
3^{\mathrm{c}}\end{array}$ & $\begin{array}{l}3.11 \\
\mathrm{c}\end{array}$ & & $09^{\mathrm{a}}$ & $\begin{array}{l}0.12 \pm 0 \\
007^{\mathrm{c}}\end{array}$ & $0.41^{b}$ \\
\hline khh & $6.15 \pm$ & $\begin{array}{l}2.00 \pm 0 \\
.00^{\mathrm{a}} \\
\end{array}$ & $\begin{array}{l}3.07 \pm 0.01 \\
\mathrm{~d}\end{array}$ & $\begin{array}{l}17.31 \pm 0.0 \\
5^{\mathrm{d}}\end{array}$ & ${ }_{d}^{75.53 \pm 0.15}$ & $\begin{array}{l}1.43 \pm 0.00 \\
7^{\mathrm{a}}\end{array}$ & $\begin{array}{l}2.33 \pm 0.00 \\
8^{\mathrm{d}}\end{array}$ & & & $\begin{array}{l}0.18 \pm 0 . \\
007^{\mathrm{a}}\end{array}$ & $2.4 \pm 0.42^{\mathrm{a}}$ \\
\hline D & 0.0446 & 0.0118 & 0.0255 & 0.1553 & 0.2451 & 0.0132 & 0.0129 & 0.0684 & 0.0120 & 0.0094 & 0.500 \\
\hline
\end{tabular}

Values are mean of five replicate determination and values after sign plus/minus ( \pm ) indicate standard deviation Superscript letters $(a-d)$ indicate significant differences $(p<0.05)$ among different rice varieties. Means with same letter within column are not significantly different $(p<0.05)$.

Thousand kernel weights were found the maximum for Pokhareli Basmati $(17.31 \mathrm{~g} \pm 0.05)$ and the minimum for Black Basmati (11.37 $\mathrm{g} \pm 0.21)$. Statistical analysis showed that there is a significant $(\mathrm{p}<0.05)$ difference among the varieties (Table 3). The bulk density was obtained highest for Black Basmati $(86.26 \mathrm{~kg} / \mathrm{hL}$ ) while minimum for Pokhareli Basmati $(75.53 \mathrm{~kg} / \mathrm{hL})$.

Cooking Quality of Rice

The Kernel elongation ratio (KER) of White Basmati, Red Basmati, Black Basmati and Pokhareli Basmati were $1.43 \pm 0.007 ; 1.62 \pm 0.011 ; 1.47 \pm 0.013$ and $1.43 \pm 0.007$, respectively (Table 3 ). The highest ratio was occurred in Red Basmati. The water uptake ratio was calculated as the ratio of the weight of cooked and uncooked rice in between at $80^{\circ} \mathrm{C}$ to $96^{\circ} \mathrm{C}$ temperatures. The water uptake ratio was found to be maximum for Black Basmati (3.11 \pm 0.01$)$ and minimum for Red Basmati $(2.18 \pm 0.011)$. There is a significant $(\mathrm{p}<0.05)$ difference among the tested varieties (Table 3). The volume expansion ratio of White Basmati, Red Basmati, Black Basmati and Pokhareli Basmati were 2.80, 2.85, 2.81 and 2.41, respectively. The statistical analysis showed, there was significantly $(\mathrm{p}<0.05)$ different between variety except in between White Basmati and Black Basmati. The percentage of gruel loss was $1.80 \%$ for White Basmati, $1.05 \%$ for Red Basmati, $2.40 \%$ for Black Basmati and $1.80 \%$ for Pokhareli Basmati. There is a significant $(\mathrm{p}<0.05)$ difference in between all varieties except White and Pokhareli Basmati (Table 3)

The starch iodine blue value showed to be 0.18 in White Basmati, 0.21 in Red basmati, 0.12 in Black Basmati and 0.18 in Pokhareli Basmati, respectively (Table 3). Our analysis showed that all the varieties except White and Pokhareli Basmati the iodine blue value changes.

\section{DISCUSSION}

The milling yield and quality of rice depend upon different factors like moisture, size and shape of paddy, type of machine (huller, polisher), time of polishing etc. The result obtained from Lab scale may be different as compared with large scale. The degree of milling among all varieties was found to be different at the same time 
of polishing (6 mins). Shape and size is an important parameter in grain marketing including milling, transportation and storage. Long grain varieties have higher chances of breakage during milling than short grain. Generally, it is assumed that higher the length-breadth ratio, higher will be a good quality (Bhattacharya 1969). According to (Khush et al 1978) size classification (length in mm), the entire observed varieties fell in the medium variety and shape classification (L/B ratio), all three falls in medium variety except one Pokhareli Basmati fell in slender variety. According to (Khush et al 1978) size/shape classification, Pokhareli Basmati falls in slender variety and rest three in medium variety, so it can be concluded that slender variety has a lower density than medium rice. According to statistical analysis, it can be predicted that the observed rice varieties were significantly different in terms of bulk density.

The maximum limit for the moisture content in rice is $16.00 \%$ (DFTQC 2006). The lower moisture better will be the storability of rice. The growth of microorganisms gets minimized at low moisture. The moisture of each variety of rice was found below the maximum value. Moisture is the important factor for the assessment of market price, higher the moisture, lower will be the market price by damaging the rice kernels. The highest moisture was found in Red Basmati and lowest in Pokhareli Basmati.

Nepalese considers the better cooking quality for the rice having higher kernel elongation ratio. A similar concept is found in many parts of the world. The kernel elongation without an increase in girth is considered to be a good quality of rice. It can be predicted that the cooking quality of Red Basmati was found to be better among all varieties examined. KER is mainly depended upon the storage condition and time. It is expected that the gruel loss should be minimum for a good cooking quality of rice. The total solids in the residual cooking liquid of Indica rice are less whereas in Japonica rice content higher gruel loss and this is the reason of stickiness of Japonica varieties. Lower values were obtained for Indica varieties while higher in case of Japonica varieties, which indicates for the better quality for Indica in comparison to Japonica variety. This is the rough and indirect method of measuring the amylose contents of rice. This test is fact indicates the fraction of total amylose soluble in water. Amylose is more soluble in hot water than amylopectin (Juliano1979). The higher value was observed for Red Basmati. Thus the higher water soluble amylose observed for this variety and lower for Black Basmati which indicates for its lower amylose content. Higher amylose content rice is non-stickiness as that of low amylose content.

In this present work, it showed that Black Basmati is stickier than that of three (Table 3). According to (Kaul et al 1982) high amylose content (greater than 25\%) may be more digestible than low amylose content. IRRI (1982) observed that all the early varieties (mature from 98-130 days) contain 21-27\% amylose; and also showed IRRI (1981) that lower amylose content results in higher gelatinization temperature of rice. Alkali score is also related to the amylose contents of rice. This test measures the chemical solubility of starch. According to (Bhattacharya 1971) high amylose content is usually associated with non-sticky (integral type) cooking characteristics and vice versa. This means that the higher the starch iodine value indicates high amylose content (non-sticky rice) having lower alkali scoring value.

Similar results have been in the present study that the Black Basmati has lower starch iodine value (low amylose content) with higher alkali score and the rest three result has just reversed value (Table 2 and 3), suggesting White, Red and Pokhareli Basmati have comparatively better quality than Black Basmati. Thus, according to the result, it can also be interpreted that higher alkali scores could result in lower gelatinization. According to (Kaul et al 1982) it is revealed that when the protein content increases, the amylose content tends to decrease and consequently the spreading value of the grain increase which may make the Kernel stickier after cooking. Variation in water absorption may be caused by all extraneous causes such as surface area of rice, chalkiness, cracked kernels and protein content. According to Bhattacharya (1971) higher the water uptake ratio, lower the gelatinization, higher the alkali value and vice-versa. Higher the water uptake better will be the quality. In the present work, the water uptake for Black Basmati seemed better. According to Perdon et al (1997) water uptake ratio depends upon the duration of storage, genetic characteristics. The amylose-amylopectin ratio of a particular variety. The water uptake ratio, volume expansion ratio is also a main role for differentiating the rice varieties into G. T. Type. Higher the volume expansion ratios, higher will be the cooking quality. The aromatic type rice exhibits the good quality characteristics such as grain elongation and volume expansion during cooking (Juliano1979). In the present work, medium varieties had shown the greater volume expansion than slender one.

\section{CONCLUSION}

Varietal differences were evident in nutritional, physico-chemical and cooking characteristics of rice. Pokhareli Basmati was found to be nutritionally rich in crude protein, crude fiber and ash with higher milling yield comparison to the other varieties. The cooking quality of Red Basmati was better in comparison to other 
varieties. This information can be utilized for devising the breeding plant to their improvements for yield keeping intact their physico-chemical and nutritional qualities.

\section{REFERENCES}

Azabagaoglu MO and O Gaytancioglu. 2009. Analyzing consumer preference to different rice varieties in Turkey. Agricultura Tropica EtSubtropica, 42:118-125.

Bhattacharya KR. 1969. Breakage of rice during milling and effect of paraboiling, Cereal Chem. 46:478-485.

Bhattacharya KR. 1971. Gelatinization temperature of rice starch and its determination. In: Proceedings of workshop on chemical aspects of rice grain quality; Inst. Los Banos, Laguna, Philippines, pp.420-424.

Bhattacharya KR. 2011. Rice quality: A guide to rice properties and analysis. Woodhead Publishing, pp.61-99.

Bocevska M, I Aldabas, D Andreevska and V Ilieva. 2009. Gelatinization behavior of grains and flour in relation to physiochemical properties of milled rice (Oryza Sativa L.). J. Food Quality 32:108-124.

Bouis HE, BM Chassy and JO Ochanda. 2003. Genetically modified food crops and their contribution to human nutrition and food quality. Trends in Food science and Technology 14, pp.191-209.

DFTQC. 2006. Food standard. Department of Food Technology and Quality Control, Babarmahal, Kathmandu, pp.38.

Gao LZ, BA Schal, CH Zhang and JZ Jia, 2002. Assessment of population genetic structure in common wild rice OryzaeRufipogonGriff using microsatellite and allozymesmarker.Theor. Appl. Genet, 106:173-180.

IRRI .1981.Annual Report 1980. International Rice Research Institute, Los Banos, Laguna, Philippines, pp. 538

IRRI. 1982. Annual Report 1981. International Rice Research Institute, Los Banos, Laguna, Philippines, pp. 467

Juliano B O. 1979. The chemical basis of rice grain quality. In: Proc. of the Workshop on Chemical Aspects of Rice Grain Quality, Int. Rice Res. Inst., Los Banos, Laguna, Philippines, p.69.

Kaul AK, MRI Khan and KM Munir. 1982. Rice quality, a survey of Bangladesh germplasm. Bangladesh Rice Research Institute, Joydebpur, Dhaka, p.178.

Khush GS, CM Paule and NM Dela Cruz. 1978. Rice grain quality evaluation and improvement at IRRI. In: Procurement of the Workshop on Chemical Aspects of Rice Grain Quality. International Rice Research Institute Philippines, pp.21-13

Khush GS. 2000. Taxonomy and origin of rice. Oxford and IBM publishing company Private limited, New Delhi, pp.5-13

MoAD. 2015. Rice varietal mapping in Nepal: Implication for development and adoption. Department of Agriculture Crop Development Directorate, Ministry of agricultural Development, Government of Nepal, pp.1-3.

NARC. 2014. Released and registered crop varieties in Nepal (1960-2013). NARC Publication No. 0040-2013/14 Communication, Publication and Documentation Division (CPDD), Nepal Agricultural Research Council, p.3.

Oko AO, E UbiB and N Dambaba. 2012. Rice cooking quality and physico-chemical characteristics: A comparative analysis of selected local and newly introduced rice varieties in Ebonyi state, Nigeria. Food Pub. Health 2(1):43-49.

Perdon AA, BP Marks, TJ Siebenmorgen and NB Reid. 1997. Effects of rough rice storage conditions on the amylograph and cooking properties of medium-grain rice Bengal. J. Cereal Chem. 74:864-867.

Rangana S. 2002. Handbook of analysis and quality control for products. Tata McGraw- Hill Publishing Co Ltd, New Delhi, pp.1-30.

Ranghino F. 1966. Evaluation of the resistance of rice to cooking as a function of the time of gelatinization of the grains. Riso 15:117-127.

Singh N, L Kaur, SN Singh and KS Sekhon. 2005. Physiochemical, cooking and textural properties of milled rice from different Indian rice cultivars. Food Chem. 89:253-259.

Tan YF, IX Li, SB Yu, YZ Xing and CG Xn. 1999. The three important traits for cooking and eating quality of rice grains are controlled by a single locus in an elite rice hybrid, Shanyou 63. Theory Appl. Genetic 99:642-648. 